\title{
Muuttuuko ihminen, ja mihin suuntaan?
}

Vilma Hänninen \& Elisa Aaltola (toim.) (2020). Ihminen kaleidoskoopissa. Inmiskäsitysten kirjoa tutkimassa. Gaudeamus. 348 sivua.

IHMINEN KALEIDOSKOOPISSA sai alkunsa yllättävästä havainnosta. Sen toinen toimittaja, professori Vilma Hänninen haravoi sosiaalitieteiden opintovaatimuksia varten koti- ja ulkomaista kirjallisuutta ihmiskäsityksistä. Ainoa löytynyt oli vuonna 1987 ilmestynyt englanninkielinen, ei enää täysin ajanmukainen teos. Monipuolinen teos paikkaa hyvin suomalaisen perusteoksen puutetta.

Kokoelma jakautuu ajallisesti kolmeen jaksoon: 500 ennen ajanlaskun alkua - 600 ajanlaskun alun jälkeen syntyneet, 1600-1800-luvuilla muotoutuneet sekä 1900-luvuilla esiin murtautuneet ihmiskäsitykset. Siten kuljetaan pitkä matka buddhalaisuuden synnystä ja vanhatestamentillisuudesta intersektionaalisuuteen ja ihmisen jalustalta pudottavaan posthumanismiin. Toimittajat mukailevat esipuheessaan kanadalaisfilosofi Charles Tayloria todetessaan, että tietty käsitys ihmisestä avaa jonkinlaisen minuuden lähteen, käsityksen hyvästä elämästä, jonka mukaan voi pyrkiä elämässään suunnistamaan.

\section{SAARENA VAI SUHTEISSA ELÄMINEN}

Alun perin tuoreet ja hyvää tarkoittavat ajatukset voivat ajan myötä latistua tai muuttua vastakohdakseen. Taylorin mukaan autenttisuuden idea voi individualismin oloissa vääntyä ihmisiä erilleen ajavaksi voimaksi. Filosofi Friedrich Nietzschen itsekseen tulemisen kehotus oli aikanaan radikaali ja emansipatorinen, mutta nyt sama ajatus hyökyy päälle kaikkialta vaativana normina. Yhteiskuntafilosofi Axel Honnethin mukaan jatkuva "itsenään oleminen" ylikuormittaa.

Arkikäsitys ihmisen itsekkyydestä ja piittaamattomuudesta on lujassa, mutta 1700-luvun skottivalistuksen edustaja James Ferguson korosti ihmisen sosiaalisuutta tutkimusmatkailijoiden tuoman tiedon pohjalta. Kaikkialla maailmassa ihmiset elävät ryhmissä, iloitsevat toistensa seurasta ja kärsivät yksinolosta. Ihminen on valmis uhrautuvaankin toimintaan, kun muut kaipaavat apua. Jako meihin ja muihin on usein jyrkkä, mutta empiirisissä tutkimuksissa löytyy myös sisäryhmäjaon ylittävää myötätuntoa. Empatia on silta itsen ja muiden välillä.

Abstraktin ja köyhdyttävän individualismin vastapainona on haluttu korostaa suhteissa oloa. Runoilija John Donne (1572-1631) kysyi, kenelle kellot soivat, ja väitti, ettei kukaan ole saari. Filosofi J. G. Herderin

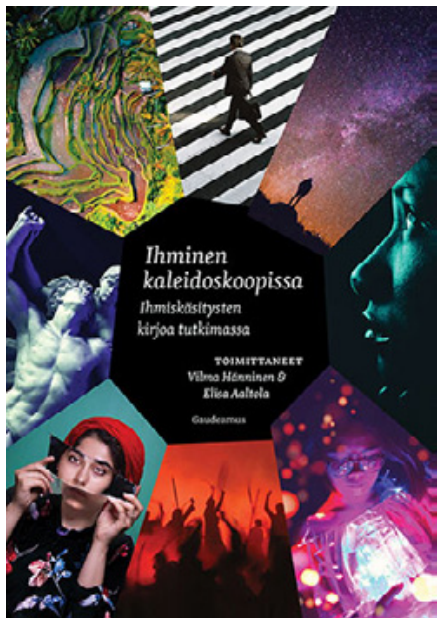

(1744-1803) mukaan myös yksilöllinen ajattelu on sosiaalista. Yhteiskuntafilosofi Karl Marx (1818-1883) painotti, että suhteissa ollessaan ja yhteiskunnallista käytäntöä luodessaan ihminen samalla luo itsensä: "Ihmisolemus ei ole mikään jollekin yksilölle ominainen abstraktio. Todellisuudessa se on yhteiskunnallisten suhteiden kokonaisuus."

\section{JÄRKI JA TUNTEET}

Antiikin filosofit Platon ja Aristoteles esittivät ihmissielun kerroksellisena. Platon kutsui osia järkisieluksi, tunteet sisältäväksi intosieluksi ja aistinautintoja tavoittelevaksi himosieluksi. Lisäksi ihmisellä nähtiin olevan ravinnosta huolehtiva kasvisielu ja liikkumisesta vastaava eläinsielu. Mitä enemmän järkisielu hallitsee muita kerroksia, sitä viisaampi ja lähempänä antiikin ylevää ihannetta ihminen on. Toisaalta Aristoteles purki dualismia ja puhui viisaista tunteista, jotka eivät ole järjelle vastakkaisia. 
Filosofi Immanuel Kant (1724-1804) katsoi, että valistus on yhtä kuin poispääsy itse aiheutetusta alaikäisyyden tilasta. Moraalin maailmanhistoriaa tutkinut Kenan Malik (1960-) näkee moraalin kehityksen paljolti juuri rationaalisuuden lisääntymisenä. Valistuksen vastareaktioksi nousi 1800-luvun kirjallisuudessa ja taiteessa romantiikka, mutta kokeellinen tiede ei menettänyt merkitystään. Mannermainen filosofia jatkoi sekä valistuksen että romantiikan perinteitä myös 1900-luvulla.

Kielellisen käänteen jälkeen ihmistieteissä on nimetty affektiivinen ja myös ruumiillinen käänne. Kirjan toimittajat käsittelevät tunteellista ihmistä. Psykologi ja filosofi William James (1842-1910) toi esiin tunteiden kehollisuuden tavalla, jota nykytutkimuskin osittain tukee. Tunteet ovat ensin kehollisia, nykykielellä kait affekteja, jotka mieli tulkitsee tunteiksi. Keho voi virittyä kulloiseenkin tilanteeseen nopeammin kuin tietoinen mieli. Affektitutkija Lisa Barrettin mukaan samantapaista tuntemusta voidaan kuvata eri tunnesanoilla, ja lapsi oppii nimeämään tuntemuksiaan eli affekteja saamansa palautteen kautta.

\section{BIOLOGIA JA MONINAISUUS}

Kasvatusfilosofi John Dewey (1859-1952) arveli, että mielen ja ruumiin suhteesta käytävät loputtomat väittelyt johtuvat usein vain käsitteellisistä sekaannuksista. Ihmis- ja yhteiskuntatieteilijät ovat ehkä pitäneet biologian huomioon ottavaa ihmiskäsitystä deterministisenä ja yhteiskunnallisuuden kieltävänä, mutta viime vuosina kuilu lienee kaventunut. Ihminen kaleidoskoopissa -teoksessa Elisa Aaltola lähestyy ihmistä osana luontoa, ja Jaana Parviainen kirjoittaa ruumiillisuudesta. Kulttuurinen sopeutuminen ja luovuus kuuluvat ihmiselle lajina, osana biologiaa, ei kulttuurille vastakkaisena. Tämäntapaista biologian ja kulttuurin yhteen kietoutumista hahmotteli jo merkittävin suomalainen sosiologi Edward Westermark (1862-1939), muistuttaa biologista ihmiskäsitystä esittelevä Tomi Kokkonen.

Evolutiivisesti voidaan selittää myös ihmisten taipumusta tehdä turhan nopeita syy-seuraus-päätelmiä tai yleistyksiä esimerkiksi ihmisryhmästä. Ympäristössä, jossa nämä piirteet aikanaan kehittyivät, oli niukasti tietoa, eikä tärkeintä ollut niinkään oikeaan osuminen vaan se, tuotetaanko riittävän usein suurin piirtein oikeansuuntaisia tuloksia. Oletukset eivät ole välttämättä tasapuolisia, vaan vaaran ja haittojen liioittelusta on savannilla ollut hyötyä selviytymisen kannalta. Tämä voi olla hyvä muistaa, kun aamuyön suden hetkellä vatvoo seuraavan päivän päälle kaatuvia uhkakuvia. Biologinen näkökulma muistuttaa myös "ihmisluonnon" ja "luonnollisuuden" suhteellisuudesta. Jos halutaan, voidaan puhua ihmisluonnosta, mutta tällöin on Kokkosen mukaan otettava huomioon lajin koko variaatio eikä vain itseä miellyttävät piirteet.

\section{KAIKKI KIRJOITTAJAT OVAT AIKALAISIAMME}

Ihmiskäsitykset eivät ole toisiaan poissulkevia eivätkä kerralla syntyneitä: uutena esitelty ajatusmalli ei välttämättä ole lainkaan uusi. Ranskalaisfilosofi Michel Serresin (1930-2019) mukaan uusissa kirjoissa on ajatuskerrostumia, laskostumia ja viiveitä eri ajoilta: "Kaikki kirjoittajat ovat aikalaisiamme". Lucretius kirjoitti noin vuonna 50 ennen ajanlaskun alkua teoksessaan De rerum natura virtaavuudesta ja kaaoksesta hyvinkin nykyaikaiseen sävyyn.

Mitra Härkönen, Aleksi Järvelä ja Raimo Kuismanen kertovat artikkelissaan mahāyānabuddhalaisuuden pyrkimyksestä dualismien kumoamiseen. Emme elä joko-tai- vaan sekä-että-maailmassa. Kaksi totuutta voi olla keskenään ristiriidassa, totuudet kumoavat toisensa ja ovat silti yhtä totta. Ihminen kokee maailmaa aisteillaan, mutta aistien kohteilla tai kokijalla ei ole mitään pysyvää olemusta. Kieli on 
paradoksaalista ja sisältää oman negaationsa: se viittaa erillisiin objekteihin, mutta samalla ei-mihinkään. Tuhansia vuosia vanha oppi kuulostaa kovin nykyaikaiselta.

Pitkää dualismien purkuprojektia jatkaa myös moninaisuudesta kirjoittava Sanna Karhu. Queer-ajattelu hylkää puheet "suvaitsevaisuudesta”, koska sana viittaa siihen, että valta-asemassa oleva suvaitsee eli sietää poikkeavia ja erilaisia. Filosofi Michel Foucault (1926-1984) toi esiin, että kunkin ajan käsitys seksuaalisuudesta riippuu tavoista jäsentää tiedon ja vallan kehämäistä suhdetta.

\section{MONTAKO TRADITIOTA?}

Teoksessa on 15 artikkelia, mutta jostain syystä kustantajan takakansiteksti väittää kirjaan samalla sisältyvän myös 15 ajattelutraditiota ihmisestä. Ei kuitenkaan voi nimetä yhtä rationaalista, yhtä historiallista, yhtä ruumiillista, yhtä uskonnollista, yhtä kerroksellista, yhtä epätäydellistä tai yhtä tunteellista ajattelun traditiota, kun mukaillaan artikkelien teemoja.

Toinen kustantajalle suunnattu huomio on ikuisuusasia: nimi- ja asiahakemisto olisi tä- mäntyyppisessä artikkelikokoelmassa tarpeen. Teosta voi joka tapauksessa suositella monen alan tutkintovaatimuksiin.

\section{JUSSI ONNISMAA}

FT, dosentti, työnohjaajakouluttaja, tietokirjailija

\section{LISÄÄ AIHEESTA}

Onnismaa, J. (2017). Kadonnutta moraalin suuntaa etsimässä. Aikuiskasvatus 37(1), 57-58. https://doi.org/10.33336/ aik.88398 